УДК: 94(477.83/.86):343.2/.7(436)]"179/180"

\title{
АВСТРІЙСЬКИЙ КРИМІНАЛЬНИЙ КОДЕКС 1803 РОКУ: ПОРІВНЯЛЬНО-СТРУКТУРНИЙ АНАЛІЗ
}

\author{
М. Шуп'яна \\ Львівський національний університет імені Івана Франка, \\ вул. Університетська, 1, Львів, Україна, 79000, \\ e-mail: shupyana5@gmail.com
}

Подано огляд основних етапів кодифікації австрійського кримінального законодавства у 1790-1803 роках. Особливу увагу приділено аналізу приписів патентів імператора та їх впливу на роботу кодифікаційної комісії та текст кодексу. Встановлено, що вихідним пунктом праці кодифікаційної комісії над проектом кримінального кодексу 1803 року був текст Всезагального закону про злочини і їх покарання 1787 року та основна дискусія велася про те, які зміни необхідно внести у норми цього закону. Проаналізовано зміст та структуру Кримінального кодексу для Західної Галичини 1797 року і наголошено, що де-юре метою його прийняття було встановлення на території Східної та Західної Галичини миру та порядку, а де-факто - практичне випробування його положень. З'ясовано, що прийняття нового загальноавстрійського кримінального кодексу 1803 року було зумовлено змінами у суспільному та політичному житті імперії, а також запровадженням поділу кримінально караних діянь на злочини та тяжкі поліцейські проступки, відновленням застосування смертної кари та іншими нововведеннями, які були запровадженні нормами цього кодексу. Наголошено, що до 1848 року Кримінальний закон про тяжкі злочини та тяжкі поліцейські проступки 1803 року не зазнав якихось істотних змін і доповнень, а новий загальноавстрійський кримінальний кодекс було прийнято лише 1852 року.

Ключові слова: Кримінальний кодекс для Західної Галичини 1796 року, Й. Зонненфрельс, Францішкана, кодифікаційна комісія, тяжкі поліцейські проступки.

DOI: http://dx.doi.org/10.30970/vla.2020.70.112

Одним із важливих етапів кодифікації австрійського кримінального законодавства у XVIII-XIX століть було прийняття нового загальноавстрійського кримінального кодексу - Кримінального закону про тяжкі злочини та тяжкі поліцейські проступки у 1803 році. Цей кодекс став головним правовим інструментом у регулюванні не лише питань, пов'язаних із матеріальним кримінальним правом, а й кримінально-процесуальним правом також аж до моменту прийняття нового кримінального кодексу у 1852 році. Прийняття кримінального кодексу 1803 року, як результату правового експерименту та наслідку внесення змін і доповнень у приписи Кримінального кодексу для Західної Галичини 1797 року, було викликане не лише змінами у суспільному та політичному житті імперії, а й відновленням дії деяких інститутів кримінального права, яких не було у кримінальному кодексі 1787 року. У сучасних умовах утвердження принципів демократичної та правової держави, що наявні в нашій державі, а також процесами євроінтеграції, які в ній відбуваються, перед українським законодавцем стоїть низка завдань, чільне місце серед яких займає реформування національної правової системи загалом та іiі окремих інститутів, зокрема у галузі кримінального права. Допомогти у втіленні цього завдання може історико-правовий досвід, оскільки облік помилок минулого є

(C) Шуп’яна М., 2020 
M. Шуп'яна

ISSN 0136-8168. Вісник Львівського університету. Серія юридична. 2020. Випуск 70

гарантією уникнення їх у майбутньому, що є однією з умов ефективного реформування законодавства сучасної України.

Серед дослідників питання, пов'язаного 3 прийняттям та структурою австрійського кримінального кодексу 1803 року, необхідно назвати таких учених: Е. Кшимуський, К. Суйка-Зєлінська, О. Бальцер, А. Хиє, К. Кораниї, К. Біндінг, П. Стебельський, Ю. Макаревіч, С. Сальмонович, В. С. Кульчицький, Б. Й. Тищик, М. В. Никифорак, І. Й. Бойко та інші, які проаналізували та розвинули існуючі наукові уявлення 3 цього питання. Однак, незважаючи на вказане, необхідно зазначити, що у сучасній юридичній літературі з історії держави і права, мають місце поки що початкові спроби дослідження цього питання. Саме тому метою цієї статті є поглиблення історико-правових знань про основні етапи кодифікації австрійського кримінального законодавства у 1790-1803 роках, процес прийняття, його законодавче регулювання та вплив на нього положень імператорських патентів, особливості структури та зміст Кримінального закону про тяжкі злочини та тяжкі поліцейські проступки 1803 року.

Продовжуючи започатковану імператрицею Марією Терезією та іiі сином Йосифом II політику «освіченого абсолютизму» у сфері кримінального права, наступник імператора Йосифа II Леопольд II намагався пом'якшити суворість Кримінального закону про злочини та їх покарання 1787 року, який, попри всі його нововведення, все ж не повною мірою подолав жорстокість у покараннях та інші недоліки Кримінального кодексу Марії Терезії 1768 року. Наступник Йосифа II Леопольд II намагався пом'якшити суворість Всезагального закону про злочини і їх покарання 1787 року. У квітні 1790 року імператор видав патент, згідно з приписами якого усіх в'язнів, яких було засуджено до покарання у вигляді ув'язнення, поєднаного 3 громадським роботами, що полягали у праці на буксирувальних суднах, звільнялося від виконання цих робіт. Наступним важливим кроком у питанні гуманізації кримінального законодавства було видання Леопольдом II 7 квітня 1790 року патенту, яким було відмінено такі покарання, як удари батогами чи палицями, таврування i приковування ланцюгами [4, с. 15]. Згадані патенти започаткували реформу виконання покарань та стали основою для подальшої роботи над кодифікацією австрійського кримінального законодавства. Леопольд II також створив кодифікаційну комісію та поставив перед нею завдання - розробити новий кримінальний закон, однак він не дожив до представлення проекту цього закону.

Працю над кодифікацією кримінального права продовжив уже його наступник імператор Франц II. Необхідно наголосити, що незважаючи на те, що ця праця відбувалася за несприятливих політичних умов, зокрема, посилення впливу прихильників відновлення феодального законодавства, їі виконували люди, які працювали над кодифікацією кримінального законодавства за часів імператора Йосифа II, які не мали жодного наміру відходити від основних здобутків, що були втілені у Всезагальному законі про злочини і їх покарання від 13 січня 1787 року. Вихідним пунктом праці кодифікаційної комісії був текст Всезагального закону про злочини і ïx покарання, основна дискусія велася про те, які зміни необхідно внести у норми цього закону. До цього питання з часом додалося ще одне: чи необхідно відновлювати смертну кару ? Цю дискусію зупинив імператор, який 2 січня 1795 року своїм патентом відновив застосування смертної кари у випадку вчинення державної зради. Цей патент став важливою складовою подальшої роботи кодифікаційної комісії [11, s. 386]. Праця комісії ознаменувалася оприлюдненням 17 червня 1796 року Францом II одного із проектів кримінального кодексу, який розробив австрійський криміналіст Й. Зонненфельс, під назвою «Кримінальний кодекс для Західної Галичини», який був 
покладений в основу загальноавстрійського кримінального кодексу від 3 вересня 1803 року. Цей кодекс набрав чинності 1 січня 1797 року і поширював свою дію лише на територію Східної та Західної Галичини. На всій іншій території Австрійської імперії продовжували діяти норми Всезагального закону про злочини i їх покарання від 13 січня 1787 року з урахуванням внесених змін та доповнень [7, с. 45]. Як зазначав законодавець, метою впровадження цього кодексу лише на території Галичини є: «встановлення на цій території миру та порядку», а де-факто - 3 метою практичного випробування його положень. Кримінальний кодекс для Західної Галичини регулював питання і матеріального, і процесуального кримінального права. Цей кримінальний закон складався 3 двох частин, поділених на п'ятсот шістдесят вісім статей [8, S. 1]. Перша його частина (§ 1-232) містила норми про злочини і їх покарання, друга $(\S 233-$ 568) була присвячена питанням кримінального процесу. Незважаючи на прийняття цього кодексу, праця кодифікаційної комісії не була припинена, оскільки його впроваджували на території Галичини, як зазначалося вище, для його практичного випробування, тобто був правовим експериментом австрійської влади.

Подальшу роботу над новим кримінальним кодексом кодифікаційна комісія продовжила після 1 січня 1797 року. Протягом усього 1797 року кодифікаційна комісія вивчала позиції судових органів краю щодо норм цього кодексу. Під час дослідження згаданих позицій Й. Зонненфельсом було запропоновано доповнити Кримінальний кодекс для Західної Галичини нормами про тяжкі поліцейські проступки, оскільки нормами цього кодексу тяжкі поліцейські проступки не були кримінально караними діяннями. Кодифікаційна комісія схвалила цю пропозицію та доручила йому розробити главу «Про тяжкі поліцейські проступки». На завершальному етапі праці над проектом нового кодексу комісія прийняла рішення про те, що відповідальними за остаточний текст проекту кримінального кодексу будуть Й. Зонненфельс та Ф. Зейлер [17, s. 115-116].

На основі норм Кримінального кодексу для Західної Галичини 1796 року та результатів його практичного випробування на території Західної та Східної Галичини кодифікаційна комісія розробила проект нового загальноавстрійського кримінального кодексу. Цей проект був схвалений імператором Францом II i 3 вересня 1803 року оприлюднений ним під назвою «Кримінальний закон про тяжкі злочини та тяжкі поліцейські проступки» (в історико-правовій науці його ще називають Францішканою) [3, с. 33]. Згідно з цісарським патентом, яким було оприлюднено цей кодекс, зазначалася, що цей кодекс набирає чинності 31 січня 1804 року. У цьому патенті наголошено, що законодавчі приписи, зокрема, приписи пов'язані зі системою покарань та їх застосуванням, враховуючи зміни у суспільному та політичному житті імперії, що відбулися за останні роки, потребують перегляду та удосконалення. Вищенаведене, а також запровадження поділу кримінально караних діянь на злочини та тяжкі поліцейські проступки, відновлення застосування смертної кари, а також інші нововведення, як вказано у згаданому патенті, спонукали до розроблення та прийняття цього кодексу [19, s. 319].

Кримінальний кодекс 1803 року складався з двох частин (перша частина була присвячена тяжким злочинам, а друга тяжким поліцейським проступкам), кожна 3 них мала по два розділи, один із яких стосувався норм матеріального кримінального права, а другий - кримінального процесу [6, с. 70]. Важливим аспектом аналізу структури кримінального кодексу 1803 року є іï порівняння зі структурою Всезагального закону про злочини і їх покарання 1787 року та Кримінального кодексу для Західної Галичини 1797 року, оскільки ці два акти, як випливає 3 наведеного, стали підгрунттям для нього. Перш за все необхідно наголосити, що 
M. Шуп'яна

ISSN 0136-8168. Вісник Львівського університету. Серія юридична. 2020. Випуск 70

кримінальний кодекс 1803 року, як і Кримінальний кодекс для Західної Галичини 1797 року містив як норми матеріального кримінального права, так і норми, що регулювали процесуальні відносини, на відміну від кримінального кодексу 1787 року, нормами якого регулювалися лише питання матеріального кримінального права. Кодекс 1803 року, як і кодекс 1787 року складався 3 двох частин, нумерація статей у яких розпочиналася з 1 (у кодексі 1803 року - Ч. I (§ 1-557); Ч. II (§ 1-459), а у кодексі 1787 року - Ч. I (§ 1-126); Ч. ІІ (§ 1-98)), на відміну від кодексу 1797 року нумерація статей, у двох частинах якого була спільна, тобто не розпочиналася з $\S 1$ (§ 1-568). Кримінальний кодекс 1803 року, як і кримінальний кодекс 1797 року, на відміну від кримінального кодексу 1787 року, не містив вступної частини (у кримінальному кодексі 1803 року та кримінальному кодексі 1797 року вона називалася «Про предмет регулювання даного закону»). Цікавим, у аспекті структурної побудови, є розділ 1 ч. I Кримінального кодексу для Західної Галичини 1797 року «Про злочини». Цей розділ було поділено на Вступ та розділ 1. У Вступі було дано визначення злочину, а також відмежовано злочин від тяжкого поліцейського проступку, а у Розділі 1 було врегульовано питання вини, незакінченого злочину, а також деталізовано інші ознаки злочину. Щодо кодексу 1803 року, то, на відміну від кодексу 1797 року, Розділ 1 «Про злочини та покарання за них» ч. І цього кодексу був цілісним [17, s. 117-118].

Тяжкі злочини згідно з нормами Кримінального закону про тяжкі злочини та тяжкі поліцейські проступки 1803 року були віднесені до юрисдикції судів, а тяжкі поліцейські проступки до юрисдикції адміністративних органів - поліції та губернських правлінь. Тяжкими поліційними проступками були усі кримінально карані діяння (дія або бездіяльність), що були вчинені неумисно, а також легкі тілесні ушкодження та діяння, що порушували добрі звичаї. Кримінальний кодекс 1803 року відновив застосування, скасованого Йозефіною поняття давності скоєння злочину, як підстави для звільнення від кримінальної відповідальності за вчинення тяжких злочинів та тяжких поліцейських проступків. Подружня зрада, проституція, а також проступки проти релігії та звичаїв, що за кримінальним кодексом 1787 року належали до категорії проступків, відповідно до норм нового кодексу були віднесені до категорії тяжких злочинів. Францішкана скасувала такий наслідок притягнення до кримінальної відповідальності, як загальна конфіскація майна. Кримінальний кодекс 1803 року передбачав можливість пом'якшення покарання та дострокового звільнення від відбування покарання у вигляді ув'язнення [13, s. 238]. Відповідно до норм кодексу покарання могло бути пом'якшено, якщо за злочин передбачалось ув'язнення строком понад 5 років (тоді можна було замінити його ув'язненням на менший термін) та якщо такий злочин було вчинено 3 необережності чи вперше або якщо могла постраждати родина засудженого, зокрема, якщо він був іiі годувальником. Порівняно 3 кримінальним кодексом 1787 року, кодекс 1803 року зменшив максимальний строк ув'язнення - у кодексі 1787 року - 100 років, а у кодексі 1803 року - 20 років [4, с. 78]. Проте, кримінальним кодексом 1803 року було передбачено пожиттєве ув'язнення. До кримінально караних діянь кримінальний закон про тяжкі злочини та тяжкі поліцейські проступки від 3 вересня 1803 року відносив: державну зраду й інші вчинки, що порушують державний порядок і громадський спокій; бунти та повстання; “публічне насильство" (до якого відносили посягання на державних урядовців, напад на чужий маєток чи будинок, захоплення силою людини, безправне обмеження особистої свободи, викрадення дівчини чи чужої жінки); зловживання владою; підробка документів і грошей; образа релігії (образа Бога, офіційної 
релігії, схиляння християн до віровідступництва, пропагування атеїзму, створення сект); згвалтування; скотоложство; злочини проти людства; вбивство; аборт; підкинення дитини; тілесні ушкодження; поєдинок; підпал; крадіжка; грабунок; двоєженство; надання допомоги злочинцеві та інші протиправні діяння [7, с. 47].

Відповідно до норм кримінального кодексу 1803 року було залишено смертну кару за державну зраду, вбивство, підробку грошей і підпал. Проте смертні вироки імператор, використовуючи право помилування, в переважній більшості випадків замінював ув'язненням, що в умовах розпаду феодально-кріпосницького ладу повинно було створити популярність абсолютистській владі й зміцнити віру народних мас у доброго імператора. Смертну кару виконували через повішення. 3 1304 смертних вироків, винесених судами з 1803 року до 1848 року, виконано лише 448, а всі інші були замінені позбавленням волі на різні строки [2, с. 305].

Відповідно до положень Кримінального закону про тяжкі злочини та тяжкі поліцейські проступки 1803 року інквізиційний характер кримінального процесу значно посилювався. Домінуючу роль у порушенні справи, збиранні доказів, залученні свідків, експертів продовжували виконувати поліційні та судові органи. Часто вирок підсудному виносили за його відсутності [18, s. 457]. Кримінальний кодекс 1803 року передбачав застосування покарань до підсудного за відмову надати свідчення чи визнати вину. Підсудний навіть не міг взяти собі захисникаадвоката, бо захист його інтересів кодекс уважав обов'язком судді. Кримінальний процес був таємним та письмовим 3 формальною оцінкою доказів. Згідно 3 приписами цього кодексу, вироки у справах про державну зраду, бунт і повстання, публічний гвалт, зловживання владою, фальшування грошей і документів, образу релігії повинні бути перед їх оголошенням затверджені вищою судовою інстанцією $[19$, s. 486]. 3 метою швидкої розправи з особливо небезпечними для кріпосників особами кодекс передбачав скорочене судочинство. Для цього були введені так звані наглі суди. Судочинство у цих судах провадили за спрощеною процедурою, без дотримання звичайних формальностей, а вирок мусив бути винесений i виконаний упродовж 24 годин. Вироки наглих судів оскарженню не підлягали. Смертна кара - єдине покарання, яке застосовували ці суди [10, s. 28].

До 1848 року Кримінальний закон про тяжкі злочини та тяжкі поліцейські проступки не зазнав якихось істотних змін і доповнень, хоча робота над новим кримінальним кодексом розпочалась уже у червні 1817 року, коли було створено кодифікаційну комісію для перегляду кримінального кодексу 1803 року. Проекти 1823 і 1824 років так і не були санкціоновані імператором. Одним із важливих поштовхів для поступового перегляду положень діючого кримінального законодавства Австрійської імперії та відновлення роботи кодифікаційної комісії над проектом нового кримінального кодексу стала революція 1848-1849 років. Чинним i надалі залишався кримінальний кодекс від 3 вересня 1803 року, але уже зі змінами [15, s. 403]. Зокрема, до австрійського кримінального кодексу 1803 року було внесено такі зміни: розпорядженням міністра юстиції від 22 травня 1848 року було скасовано застосування покарання - биття різками та палками, як основного, а також додаткового покарання - виставлення винної особи на публічний огляд; імператорським патентом від 17 січня 1850 року було декриміналізовано самовбивство та скасовано застосування таких покарань: найтяжчого ув'язнення та роботи на галерах [9, s. 450]. Застосування кримінального кодексу 1803 року значно ускладнило прийняття кримінально-процесуального кодексу від 17 січня 1850 року [18, s. 324]. Необхідно зазначити, що кодекс 1850 року не поширював своєї дії на територію Галичини. Кримінально-процесуальний кодекс від 17 січня 
M. Шуп'яна

ISSN 0136-8168. Вісник Львівського університету. Серія юридична. 2020. Випуск 70

1850 року впроваджував поділ кримінально караних діянь на тяжкі злочини, нетяжкі (звичайні) злочини та проступки. Водночас чинний кримінальний кодекс 1803 року зберігав поділ на тяжкі злочини та тяжкі поліцейські проступки, що спричиняло колізії у застосуванні згаданих норм матеріального та процесуального кримінального права [12, s. 367]. Враховуючи вищенаведені факти, у березні 1850 року кодифікаційна комісія подала імператору новий проект кримінального кодексу, який було санкціоновано патентом імператора Франца Йосифа I від 27 травня 1852 року, як новий кримінальний кодекс для всієї Австрійської імперії кримінальний закон про тяжкі злочини, нетяжкі (звичайні) злочини та проступки. Цей кодекс набрав чинності 1 вересня 1852 року i, як зазначалося в патенті імператора, яким його введено в дію, «кримінальний закон 1852 р. є новим виданням кримінального закону про тяжкі злочини та тяжкі поліцейські проступки від 3 вересня 1803 р., з врахуванням усіх змін та доповнень, внесених законами, виданими після 1803 р., а також він вводить в дію деякі нові положення». Отже, до 1 вересня 1852 року питання кримінального права регулювали норми кримінального кодексу 1803 року [16, s. 202]. Незважаючи на те, що кримінальний закон про тяжкі злочини, нетяжкі (звичайні) злочини та проступки 1852 року був доповненою редакцією кримінального кодексу 1803 року, все ж він відрізнявся від нього за зовнішньою структурою і за змістом. У аспекті аналізу структури кримінального кодексу 1803 року важливим $є$ також порівняння структури цього кодексу та кодексу 1852 року. Отже, відмінності кримінального кодексу 1803 року та кримінального кодексу 1852 року щодо структури: 1) кримінальний кодекс 1852 року містив лише норми матеріального кримінального права, на відміну від кримінального кодексу 1803 року, який містив також і норми, що регулювали процесуальні відносини (питання процесуального права до 1853 року регулювалися нормами кримінального кодексу 1803 року та кримінально-процесуального кодексу від 17 січня 1850 року, з 1853 року до 1873 року - законом про кримінальне судочинство від 29 липня 1853 року, а з 1873 року до 1918 року - нормами кримінально-процесуального кодексу від 23 травня 1873 року); 2) кримінальний кодекс 1852 року складався 3 двох частин, нумерація статей у яких була спільна, тобто не розпочиналася $3 \S 1$ (§ 1-532), а кодекс 1803 року складався з двох частин, нумерація статей у яких розпочиналася $3 \S 1$ (Ч. I (§ 1-557); Ч. II (§ 1-459)); 3) кримінальний кодекс 1852 року не містив великої кількості наукових дефініцій, як це було у кодексі 1803 року; 4) кримінальний кодекс 1852 року, на відміну від кримінального кодексу 1803 року, не містив вступної частини (у кримінальному кодексі 1803 року вона називалася «Про предмет регулювання даного закону») [5, с. 317].

Отже, Кримінальний закон про тяжкі злочини та тяжкі поліцейські проступки 1803 року, став новим етапом у розвитку кримінального законодавства та кримінального права загалом, оскільки у його нормах ми бачимо продовження демократичних перетворень, що були закладені попередніми кримінальними законами 1768 та 1787 років. Незважаючи на те, що у ньому було зроблено невеликий «крок назад», порівняно з кодексом 1787 року, оскільки кодексом 1803 року було відновлено застосування смертної кари та знову об'єднано норми матеріального та процесуального кримінального права в одному акті, він став новим етапом у розвитку кримінального законодавства та зберіг тенденцію реформування кримінального законодавства у напрямі його гуманізації. Зокрема, кримінальним кодексом 1803 року було впроваджено інститут пом'якшення покарання, зменшено максимальний строк тривання ув'язнення до 20 років (за кодексом 1787 року 100 років) та скасовано загальну конфіскацію майна винної особи, як наслідок притягнення до кримінальної відповідальності. 
1. Апарат управління Галичиною у складі Австро-Угорщини / В. С. Кульчицький, І. Й. Бойко, О. І. Мікула, І. Ю. Настасяк. Львів, 2002. 82 с.

2. Бойко I. Й. Кримінальні покарання в Україні (IX-XX ст.): навч. посібник. Львів : ЛНУ ім. Івана Франка, 2013. 408 с.

3. Кульчицький В. Застосування кодексів австрійського права на території Галичини // Третя Всеукраїнська конференція “Стан кодифікаційного процесу в Україні: системність, пріоритети, уніфікація”: тези. Київ: Українська правнича фундація, 1995. С. 32-34.

4. Никифорак М. В. Джерела кримінального та кримінально-процесуального права на Буковині у 1775-1918 pp. // Наук. вісник Чернівецьк. ун-ту: зб. наук. праць. Чернівці: ЧДУ, 2000. Вип. 91: Правознавство С. 14-17.

5. Стебельський П. Австрийське карне право. Після викладу проф. П. Стебельського. 1902/1903. Львів: Накладом “Кружка правників” в “Акад. Громаді”. 1903. 419 с.

6. Тищик Б. Й. Історія держави і права Австрії та Австро - Угорщини (Х ст. - 1918 р.): навч. посібник. Львів: Юрид. факультет Львів. нац. ун-ту ім. Івана Франка, 2003. 80 с.

7. Шуn'яна М. Ю. Система покарань за австрійським кримінальним кодексом 1852 р. та практика їх застосування у Східній Галичині: монографія. Львів: 2017. 252 с.

8. Allgemeine Gerichtsordnung für Westgalizien. Wien: Gedrudckt bei J. Kraschanski, 1796. S. 1-2.

9. Balzer O. Historia ustroju Austryi w zarysie, nakladem K. S. Jakubowskiego. Lwów, 1899. $600 \mathrm{~s}$.

10. Hye A. Beitrag zur österreichischen Strafrechts-Geschichte. Wien: Verlag vom Bayerische Staatsbibliothek, 1844. $34 \mathrm{~s}$.

11. Kallas M., Krzymkowski M. Historia ustroju i prawa w Polsce 1772/1795-1918. Warszawa: PWN, 2006. $502 \mathrm{~s}$.

12. Koranyi K. Powszechna historia państwa i prawa. Warszawa : PWN, 1966. T. 3. 456 s.

13. Krzymuski E. Wykład prawa karnego ze szczególnym uwzględnieniem ustaw austriackich. T. 1. Kraków: Nakladem J. K. Żupańskiego \& K. J. Heumanna, 1887. $340 \mathrm{~s}$.

14. Krzymuski E. Wykład procesu karnego austriackiego. Kraków: Nakładem księgarni Leona Frommera, 1910. $535 \mathrm{~s}$.

15. Kudler J. Erklärung des Strafgesetzes über schwere Polizei-Uebertretungen, mit Berücksichtigung der auf dasselbe sich beziehenden, später erlassenen Gesetze und Erläuterungen. Wien, 1836. $576 \mathrm{~s}$.

16. Makarewicz J. Prawo karne ogólne. Kraków: Nakładem księgarni Leona Frommera, 1914. $288 \mathrm{~s}$.

17. Salmonowicz S. Prawo karne oświeconego absolutyzmu. Z dziejów kodyfikacji karnych przełomu XVIII-XIX w. Toruń, 1966. 295 c.

18. Sójka-Zielinska K. Historia prawa. Wyd. 12. Warszawa: Lexis Nexis, 2008. 405 s.

19. Strafgesetz über Verbrechen und schwere Polizei-übertretungen von 3 September 1803, Justizgesetzsammlung von 1798 bis 1803 . Wien, 1816. S. 318-494.

\section{References}

1. Kul'chyts'kyy, V. S., Boyko, I. Y., Mikula, O. I., Nastasyak, I. YU. (2002). Aparat upravlinnya Halychynoyu u skladi Avstro-Uhorshchyny / L'viv. (in Ukrainian).

2. Boyko, I. Y. (2013). Kryminal'ni pokarannya v Ukrayini (IX-XX st.): navch. posib. L`viv: L'vivs'kyy natsional'nyy universytet imeni Ivana Franka, L'viv. (in Ukrainian).

3. Kul'chyts'kyy, V.S. (1995). Zastosuvannya kodeksiv avstriys'koho prava na terytoriyi Halychyny. Kyyiv: Ukrayins'ka pravnycha fundatsiya. (in Ukrainian).

4. Nykyforak, M. V. (2000). Dzherela kryminal'noho ta kryminal'no-protsesual'noho prava na Bukovyni u 1775-1918 rr. Naukovy Visnyk Chernivetskoho Universitetu: Zbirnyk Naukovyh Prats. Jurisprudance, 91. (in Ukrainian). 
5. Stebel's'kyy, P. (1903). Avstryys'ke karne pravo. Pislya vykladu prof. P. Stebel's'koho. L'viv : Nakladom "Kruzhka pravnykiv" v "Akad. Hromadi".(in Ukrainian).

6. Tyshchyk, B. Y.(2003). Istoriya derzhavy i prava Avstriyi ta Avstro-Uhorshchyny (X st. 1918 r.): navch. posib. L`viv: L'vivs'kyy natsional'nyy universytet imeni Ivana Franka, L'viv. (in Ukrainian).

7. Shup"yana, M. YU. (2017). Systema pokaran' za avstriys'kym kryminal'nym kodeksom 1852 r. ta praktyka yikh zastosuvannya u Skhidniy Halychyni. L`viv. (in Ukrainian).

8. Allgemeine Gerichtsordnung für Westgalizien. (1796). Wien: Gedrudckt bei J. Kraschanski, 1796. (in German).

9. Balzer, O. (1899). Historia ustroju Austryi w zarysie, nakladem. Lwów: K. S. Jakubowskiego. (in Polich).

10. Hye, A. (1844). Beitrag zur österreichischen Strafrechts-Geschichte. Wien: Verlag vom Bayerische Staatsbibliothek. (in German).

11. Kallas, M. (2006). Historia ustroju i prawa w Polsce 1772/1795-1918. Warszawa: PWN. (in Polich).

12. Koranyi, K. (1966). Powszechna historia państwa i prawa. T. 3. Warszawa: PWN. (in Polich).

13. Krzymuski, E. (1887). Wykład prawa karnego ze szczególnym uwzględnieniem ustaw austriackich. T. 1. Kraków: Nakladem J. K. Żupańskiego \& K. J. Heumanna. (in Polich).

14. Krzymuski, E. (1910). Wykład procesu karnego austriackiego. Kraków: Nakładem księgarni Leona Frommera. (in Polich).

15. Kudler, J. (1836). Erklärung des Strafgesetzes über schwere Polizei-Uebertretungen, mit Berücksichtigung der auf dasselbe sich beziehenden, später erlassenen Gesetze und Erläuterungen. Wien. (in German).

16. Makarewicz, J. (1914). Prawo karne ogólne. Kraków: Nakładem księgarni Leona Frommera. (in Polich).

17. Salmonowicz, S. (1966). Prawo karne oświeconego absolutyzmu. Z dziejów kodyfikacji karnych przełomu XVIII-XIX w. Torun. (in Polich).

18. Sójka-Zielinska, K. (2008). Historia prawa.Warszawa : Lexis Nexis. (in Polich).

19. Strafgesetz über Verbrechen und schwere Polizei-übertretungen von 3 September 1803, Justizgesetzsammlung von 1798 bis 1803. (1816). Wien. (in German).

\section{AUSTRIAN CRIMINAL CODE OF 1803: COMPARATIVE AND STRUCTURAL ANALYSIS}

\section{Shupyana}

Ivan Franko National University of Lviv,

1, Universytetska Str., Lviv, Ukraine, 79000, e-mail: shupyana5@gmail.com

The article deals with the main stages of Austrian criminal legislation codification in 17901803. The special attention is paid to the analysis of Emperor's Patents and their influence on the work of codification commission and text of Code. It is determined that the text of the Universal Law on crimes and punishments of 1787, was the starting point of codification commission work on the draft of the Criminal Code of 1803, and the main discussion concerned the amendments to the norms of this Law that were to be made. The contents and the structure of the Criminal Code for Western Galicia of 1797, are analyzed. This Code regulated the issues of substantive, as well as of procedural criminal law. The author stresses that de jure it was enacted to establish peace and order in the territory of Eastern and Western Galicia, and de facto - for the practical test of its provisions. It is elucidated that enactment of 
the new all-Austrian Criminal Code of 1803, was determined by the changes in social and political life of Empire, as well as by the introducing the division of criminal law-breakings into crimes and serious police offenses, the resumption of death penalty and the other innovations provided by this Code. The Criminal Code of 1803, comprised two parts (the first one was devoted to serious crimes, and the second one - to serious police offenses), and each of them consisted of two sections: one dealing with the substantive law norms, and the other - with criminal procedural norms. In terms of structure, it is worth considering Section 1 "On crimes and punishments" of Part 1 of the Code that unlike Section 1 of Part 1 of the Criminal Code for Western Galicia of 1797, was integral. Section 1 of Part 1 of the Criminal Code for Western Galicia was divided into Introduction and Section 1. The Introduction provided the definition of crime, as well as the differentiation between crime and serious police offenses; Section 1 dealt with the issues of guilt, incomplete crime and detailed the other features of crime. The author stresses that the Criminal Law on crimes and serious police offences of 1803, wasn`t altered or amended until 1848, and new all-Austrian Criminal Code was enacted just in 1852 . Although the work on the new Criminal Code started in June 1817, when the codification commission was formed for re-examining the Criminal Code of 1803, but Emperor never approved the draft codes provided by the commission in 1823 and 1824 .

Keywords: Criminal Code for Western Galicia of 1797, J. Sonnenfels, Franzishkana, codification commission, serious police offenses.

Стаття: надійшла до редакції 07.03.2020 прийнята до друку 12.06.2020 